\title{
The Effect of Peer-Mediated Adaptive Physical Activity Program on Problem Behaviors of Mentally Handicapped Students
}

\author{
Oğuz Kaan Esentürk ${ }^{1} \&$ Nuri Berk Güngör ${ }^{2}$ \\ ${ }^{1}$ Faculty of Education, Erzincan Binali Yildirim University, Erzincan, Turkey \\ ${ }^{2}$ School of Physical Education and Sport, Karamanoglu Mehmetbey University, Karaman, Turkey \\ Correspondence: Oğuz kaan Esentürk, Faculty of Education, Erzincan Binali Yildirim University, Erzincan, \\ Turkey, E-mail: esenturk954@gmail.com
}

\author{
Received: April 19, 2020 Accepted: May 20, $2020 \quad$ Online Published: May 28, 2020 \\ doi:10.5539/jel.v9n3p163 URL: https://doi.org/10.5539/jel.v9n3p163
}

\begin{abstract}
The aim of this study was to investigate the effect of peer-mediated adaptive physical activity program on problem behaviors of mentally handicapped students. Eight mentally handicapped students and eight peer students with normal development participated in this study, which was designed according to a sequential descriptive design. In the research, peer education program was applied to the peer students in line with the skills expected to be exhibited during the practices. In the study, Problem Behavior Sub-Scale (PBS), which is one of the subscales of Social Skills Rating System (SSRS) developed by Gresham and Elliot (1990) and Turkish adaptation by Sucuoglu and Ozokcu (2005) was used as a quantitative data collection tool. As a qualitative data collection tool, semi-structured interview form was used. The Friedman test was used to analyze the quantitative data, and Wilcoxon Signs test was used to determine the source of the difference. Significance value was determined as 0.05 . In the analysis of qualitative data, content analysis was applied. The quantitative findings of the study showed that the peer-mediated APA program was effective on the problem behaviors of mentally handicapped students and that the skills acquired as a result of the practice were maintained by the children three weeks after the completion of the practices. In the qualitative findings, the teachers stated that after the peer-mediated APA program, there were positive developments in the ability of mentally handicapped students to experience push-pull, touch discomfort, fear, trust, power control with their peers and to act in accordance with the instructions. The obtained qualitative and quantitative findings showed that peer mediated APA program had positive effects on the problem behaviors of mentally handicapped students.
\end{abstract}

Keywords: adaptive physical activity, peer-mediated, mentally handicapped, inclusive, physical education

\section{Introduction}

\subsection{Introduce the Problem}

Problem behaviors can be defined as behaviors that prevent an individual from learning a new skill, cause $\mathrm{him} /$ her to stay out of learning environments, harm himself/herself or others and also do not comply with the social norms of the society in which the individual lives (Zarkowska \& Clements, 1994). Factors leading to problem behaviors appear in various ways; it is thought that mental disability is a major factor in explaining the reasons why these behaviors are exhibited and therefore individuals with this disability are likely to exhibit problem behaviors (Russell \& Forness, 1985). As a matter of fact, the studies (Duker, Van Druenen, Jol, \& Oud, 1986; Freund \& Reiss, 1991; Semmel \& Gao, 1992) show that mentally handicapped individuals exhibit more problem behaviors than normal developing individuals. In addition, some studies (Holden \& Gitlesen, 2006; Jones et al., 2008; Lundqvist, 2013; Sigafoos, Elkins, Kerr, \& Attwood, 1994) state that estimated ratio of mentally handicapped individuals to have behavioral problems ranges from $10 \%$ to $19 \%$. However, in addition to the dominant effects of mental disability, problem behaviors are more likely to occur in people with additional disorders such as visual impairment, hearing impairment (Cooper, Smiley, Jackson et al., 2009; Jones et al., 2008; Kiernan \& Kiernan, 1994; Poppes, van der Putten, \& Vlaskamp, 2010). Thus, it is clear that problem behaviors are not an undesirable type of behavior that occurs only due to mental disability.

Among the most common problem behaviors in mentally handicapped individuals are: off-duty behaviors, hyperactivity, dysfunctional repetitive stereotypic behaviors, aggressive behaviors towards oneself and others, 
non-compliance with instructions, aggression, carelessness, anxiety, separation anxiety, pessimism, introvert, inappropriate speech, day and night wetting, crying, whining, lying, mocking others, sexual behaviors towards others (Acar \& Batu, 2001; Antshel, Phillips, Gordon, Barkley, \& Faraone, 2006; Bhatia, Kabra, \& Sarpa, 2005; Çiftçi \& Ince, 2002; Dykens, 2000; Freund \& Reis, 1991; Kerker, Owens, Zigler, \& Horwitz, 2004; Ozen, Colak, \& Acar, 2002; Polloway, Epstein, \& Cullinan, 1985; Rush, Bowman, Eidman, Toole, \& Mortenson, 2004; Vatter, 1998; Kaner, 2009).

Problem behaviors are behaviors that negatively affect the acceptance of mentally handicapped individuals and their interaction with other individuals. When an individual is an adult, it is necessary to prevent, eliminate or control problem behaviors in order to live independently or least dependent in the society and to participate actively in the community life (Sucuoğlu, 2003). Therefore, many intervention programs have been developed and implemented in order to eliminate the problem behaviors of mentally handicapped individuals (Acar, 2000; Acar \& Batu, 2001; Crnic, Hoffman, Gaze, \& Edelbrock, 2004; Çiftçi \& Tabak, 1997; Kerker, Owens, Zigler, \& Horwitz, 2004; Matson, Minshawi, Gonzales, \& Mayville, 2006). These include peer-mediated practices that bring together individuals with disabilities and those with normal development without limitation.

Peer-mediated practices create effective results on all areas of development of individuals with disabilities (Brown, Odom, \& McConnell, 2008; Carter \& Hughes, 2005; Zascavage \& Winterman, 2009). In this method of practice, peer models support the learning of individuals with special needs and offer them the opportunity to repeat what they have learned. Individuals with special needs who spend time with their peers gain a sense of independence, see new behavior patterns and shape the concept of self more easily (Disalvo \& Oswalt, 2002; Leaf et al., 2009).

In the literature, peer-mediated implementation of many practices is considered important in terms of increasing the effectiveness of the practice. Another area of discipline that is suggested to have positive effects on mentally handicapped individuals is peer-mediated exercise. In a limited number of studies on mentally handicapped individuals, a positive correlation was found between sedentary lifestyle and problem behaviors (Dodson \& Mullens, 1969; Elliott, Dobbin, Rose, \& Soper, 1994; Nunley, 1965). In addition, Gabler-Halle, Halle and Chung (1993) concluded that there was a strong and consistent relationship between participation in an exercise program and changes in the behavior of mentally handicapped individuals. However, considering that only $4-9 \%$ of mentally handicapped individuals can participate in physical activities (Emerson, 2005; Messent, Cooke, \& Long, 1998), this creates a negative picture.

In the national literature, no research has been found on the effect of peer-mediated APA program on behavioral problems of mentally handicapped individuals. Therefore, it is thought that the results obtained from the present study will make important contributions to the literature.

\subsection{Purpose}

The aim of this study was to investigate the effect of peer-mediated adaptive physical activity program on problem behaviors of mentally handicapped students. For this general purpose, answers for the following sub-questions were sought.

1) Does the peer-mediated APA program make a significant difference between pre-test, post-test and follow-up test scores regarding the problem behavior level of mentally handicapped students?

2) What are the teachers' opinions on the problem behavior levels of the mentally handicapped students after the peer-mediated APA program?

\section{Method}

\subsection{Research Model}

Sequential descriptive design, one of the mixed research methods, was used in the study. Within the scope of this model, it was aimed to develop social skills levels of the mentally handicapped students by applying the peer mediated APA program to them and then to support the situation with qualitative data. Sequential Descriptive Design is a mixed method design in which quantitative data is collected and analyzed first, and then qualitative data is collected and analyzed in order to place the obtained data on solid foundations (Creswell \& Clark, 2017). In the quantitative aspect of the study, pre-test and post-test measurements were obtained by applying APA program to mentally handicapped students. In the qualitative dimension, interviews were conducted to support the findings of quantitative analysis.

\subsection{Study Groups}

The quantitative aspect of the study was carried out with sixteen children, eight mentally handicapped students 
and eight normally developing children. In the qualitative part of the study, interviews were conducted with four teachers. In the following section, mentally handicapped students are defined as "special children" and normal developing children are defined as "partner children".

\subsubsection{Special Children and Selection Process}

Eight children diagnosed with mental disability participated in the study. In addition, all special children continue their inclusive education. In the research, some prerequisites were sought in the process of determining the participating children. In addition, these prerequisites were met separately for each of the participating children. Participating children;

1) Must have been diagnosed with mental disability from official institutions,

2) Should show an inadequacy specific to the dependent variable (problem behavior) to be developed in the research,

3) Should not have any health problems in participating in practical training,

4) Should be open to sensual contact and interaction before, during and after the practice.

In the process of determining the children in accordance with the prerequisites listed above, necessary permissions were obtained from the administration of school administration, and interviews were conducted with the school counselors and classroom teachers. During the interviews, the teachers were informed about the purpose of the research, the ethical suitability and the practices to be performed. Then, it was asked to determine the children who were suitable for the prerequisites listed in the study. As a result of the evaluations of the school counselors and classroom teachers, nine children were determined in accordance with these prerequisites. However, as a result of the lack of permission from a child's family, the study was conducted with eight children. The final selection was made by discussing the prerequisite features by meeting the families, class teachers and school counselors of the six selected children at the school.

\subsubsection{Partner Children and Selection Process}

Eight children with normal development who are the peers of special children participated in the study. In the research, some prerequisites were sought in the process of determining the partner children. In addition, these prerequisites are met separately for each partner child. Partner Children;

1) Should be open to communication and interaction with special children,

2) Should have high levels of social skills according to teacher opinions,

3) Should not have any health problems in participating in practical training,

4) Should be open to sensual contact and interaction before, during and after the practice,

5) Should not have any problem behavior.

\subsection{Peer Education Process}

Before the implementation of the peer-mediated APA program, peer education was conducted to teach the partner children the behavior that should be done during the practice. The related literature (Özaydin, Tekin-Iftar, \& Kaner, 2008; Sazak \& Tekinarslan-Cifci, 2003; Stanish \& Temple, 2012; Temple \& Stanish, 2011; Yarimkaya, İlhan, \& Karasu, 2017; Yarimkaya, 2018) was used in the preparation of the peer education program. Peer education program consists of two parts. In the first part, information about the general development characteristics of special children was presented to partner children; in addition, theoretical information is given about how to interact with special children. In addition, the partner children were informed that they should not be afraid of the children exhibiting problem behavior and that this can be solved by the practices to be done. In the second part, the partner children were given information about how to present the instructions and how to manage the moments of starting and finishing the games during the practices. Peer trainings consisted of 4 30-minute sessions. Each part of the peer education consisted of two sessions.

\subsection{Environment and Tools}

The research was conducted in the multi-purpose playground. Necessary safety measures were provided for special and partner children in the playground which is approximately $25 \mathrm{~m}^{2}$. The floor of the playground is rubber and the area is covered with soft cushions. Temperature and light arrangements were within normal acceptable values. Materials such as balls, miniature goal posts and basketball hoops, funnels, pet bottles, slalom sticks, trampoline, training ladder, etc. were used in the practice process. 


\subsection{Peer Mediated APA Program}

In the study, the practices were carried out with special and partner children for twelve weeks and two days a week for 1 hour. In the process of determining the activities within the scope of the Peer-mediated APA program, the definition of the targeted dependent variable as well as the relevant literature (Menear \& Neumeier, 2015; Garcia-Villamisar \& Dattilo, 2010; Todd \& Reid, 2006; Staples et al., 2011; Srinivasan et al., 2014; Fragala-Pinkham, Haley, Rabin, \& Kharasch, 2005; Kunzi, 2015; Gutman, Raphael-Greenfield, \& Rao, 2012; Gutman et al., 2010; İlhan, 2007; İlhan, 2008; Özen, Çolak, \& Acar, 2012; Ministry of National Education, 2009; Ministry of Youth and Sports (MYS), 2014; Emmons \& Anderson, 2005) was considered. In order to eliminate the problem behaviors of the mentally handicapped students, factors such as interaction, communication, making the right contact and controlling uncontrollable power were included in the content of the activities. All practices were conducted by researchers.

\subsection{Data Collection Tools}

Data collection tools related to two different paradigms were used in the study.

\subsubsection{Quantitative Data Collection Tool}

In the scope of the research, Problem Behavior Sub-Scale (PBS), which is one of the subscales of Social Skills Rating System (SSRS) developed by Gresham and Elliot (1990) and Turkish adaptation by Sucuoglu and Ozokcu (2005) was used as a quantitative data collection tool. This subscale consists of the sub-dimensions of externalized behaviors, internalized behaviors and hyperactivity. In the sub-dimension of externalized behaviors, there are discussion, low anger control and unsuitable behaviors related to verbal and physical behaviors towards others, while the sub-dimension of internalized behaviors consists of low self-esteem, loneliness, anxiety. The sub-dimension of hyperactivity includes behaviors such as hyperactivity, inability to stand still and distraction. Zero (0) is marked if a student never does a problem behavior, one (1) is marked if s/he sometimes does it, and two (2) is marked if s/he does it very often. The total score to be obtained from PBS varies between 0 and 36. Afterwards, as a result of the factor analysis conducted by Sucuoğlu and Özokçu (2005), it was seen that the three-factor structure turned into a two-factor structure, externalized behaviors and internalized behaviors. Six items in the hyperactivity factor were included in the externalized behaviors factor. As a result of factor analysis, it was determined that two factors explained $61.79 \%$ of the total variance. In the final case of the scale, there are a total of 18 items, 12 items in the externalized behaviors factor and 6 items in the internalized behaviors factor. In addition, Cronbach's alpha coefficient was .90 for the total score of the scale, .93 for the first factor, and .86 for the second factor (Sucuoglu \& Ozokcu, 2005).

\subsubsection{Qualitative Data Collection Tool}

In the study, semi-structured interview form was used as a qualitative data collection tool. Interviewing is a tool that enables to reveal what people think, what they think and why, what are their attitudes and feelings, and the factors that direct their behavior (Ekiz, 2009). In the process of creating the questions to be included in the interview form, the related literature was examined. The questions prepared in line with the literature were revised according to the findings obtained from the quantitative part of the research. The interview form in the draft format was submitted to the evaluation of three academicians specialized in physical education, special education and Turkish. As a result of scope validity based on expert opinions, semi-structured interview form took its final form.

\subsection{Data Analysis}

Quantitative and qualitative data were analyzed separately. In the following section, information on the analysis of quantitative and qualitative data is presented.

\subsubsection{Analysis of Quantitative Data}

Before starting the analysis of the data, it was examined whether the data were suitable for normal distribution by considering Shapiro-Wilk and kurtosis-skewness coefficients. In the analysis, it was seen that the data did not have normal distribution. Therefore, the use of non-parametric tests in the analysis process was decided. Friedman test was used in the analysis of quantitative data and Wilcoxon Signs test was used to determine the source of the difference. Significance value was determined as 0.05 .

\subsubsection{Analysis of Qualitative Data}

Descriptive (thematic) analysis method was used in the analysis of qualitative data. First, voice recordings obtained from the interviews with teachers were transcribed. The data transcribed were converted into codes and categories in line with the findings of quantitative analysis. 


\subsection{Validity-Reliability}

In order to provide for the quantitative and qualitative findings valid and reliable results, some precautions are presented in the following section. In this study, Cronbach Alpha internal consistency coefficient related to the general and sub-dimensions of the measurement tool was examined in order for quantitative data to give valid and reliable results. In qualitative research, validity and reliability are considered important in terms of the appropriateness of the results reached. For this purpose, the methods, which are used to provide validity and reliability in qualitative studies, of spending a long time in the working environment, presenting the data and analyzes to the control of the researched persons and presenting the data, analyzes and comments to the experts were applied (Ekiz, 2009).

\section{Results}

In this section, qualitative and quantitative findings obtained within the scope of the research are presented in line with the research questions.

\subsection{Findings Related to the First Sub Question}

Does the peer-mediated APA program make a significant difference between pre-test, post-test and follow-up test scores regarding the problem behavior level of mentally handicapped students?

Table 1 shows pre-test, post-test and follow-up test scores regarding the problem behavior level of mentally handicapped students through the peer-mediated APA program.

Table 1. Friedman test results of pre-test, post-test and follow-up test scores on problem behavior levels of the practice group

\begin{tabular}{llllll}
\hline & $\mathrm{N}$ & Mean Rank (SO) & Chi-Square $(\mathrm{X})$ & Degree of Freedom (df) & Significance Value \\
\hline Pre-test & 8 & 3 & 14.857 & 2 & 0.001 $^{*}$ \\
Post-test & 8 & 1.25 & & & \\
Follow-up test & 8 & 1.75 & & & \\
$\mathrm{p}<0.01$ & & & & &
\end{tabular}

Note. ${ }^{*} \mathrm{p}<0.01$.

When Table 1 was examined, it was determined that the peer-mediated APA program created a significant difference between pre-test, post-test and follow-up tests (Chi-square: 14.857; $\mathrm{p}<0.05$ ). The Wilcoxon Signs test was used as a non parametric post hoc analysis in order to determine which measurements were among these differences. Test results showed that there was a significant difference between pre-test - post-test (z: $2.527 ; \mathrm{p}=$ $0.012<0.05)$ and follow-up test - pre-test $(\mathrm{z}:-2.552 ; \mathrm{p}=0.011<0.05)$. However, there was no significant difference between posttest - follow-up test scores ( $\mathrm{z}:-1.89 ; \mathrm{p}=0.059>0.05)$.

\subsection{Findings Related to the Second Sub Question}

What are the teachers' opinions on the problem behavior levels of the mentally handicapped students after the peer-mediated APA program?

In the study, peer-mediated APA program was applied to mentally handicapped students and as a result of this practice, a significant difference was found between pre-test and post-test measurements regarding problem behavior levels of special children. At the end of the practice, it was determined that the special children retain the acquisitions, which contribute to reducing the problem behaviors, three weeks after the end of the practices.

Table 2 shows the opinions of teachers about the changes in problem behaviors of special children after the applications.

Table 2. Teachers' opinions on the change in problem behavior of mentally handicapped students after the peer-mediated apa program

\begin{tabular}{ll}
\hline Categories & f \\
\hline Increase in behavior appropriate to the classroom atmosphere & 2 \\
Getting on with peers without push-pull behavior & 2 \\
Elimination of touch-related discomfort & 4 \\
Confidence acquisition & 4 \\
Decreased fears based on peer and teacher relationships & 1 \\
Acquisition of power control & 3 \\
Acquisition of behavioral models according to the instructions & 2 \\
\hline
\end{tabular}


According to Table 2, after the APA program applied to the mentally handicapped students, the teachers defined the changes regarding the problem behavior levels of the children as "Increase in behavior appropriate to the classroom atmosphere", "Getting on with peers without push-pull behavior", "Elimination of touch-related discomfort", "Confidence acquisition", "Decreased fears based on peer and teacher relationships", "Acquisition of power control", "Acquisition of behavioral models according to the instructions". In the following section, the opinions of teachers reflecting the raw form of the concepts included in the table above as a category are presented.

"...they were more often involved in behaviors that would disrupt the harmony of the lesson during the lessons in the classroom prior to practice. After the development of peer relations, the duration of adjustment within the class increased. After the practice, the problem behaviors reflected in the classroom atmosphere decreased due to the better relations with friends" (S1).

“...there was almost no moment when there was no push-pull with friends in any kind of activities in and out of the classroom. I think there is a decrease in the unwanted behavior to each other after discharging their energy after the practices" (S3).

"...they did not tolerate the long-term touch of classmates or teachers to them. However, playing skin-based games after the practices provided a significant softening of these reactions" (S4).

“...he could harm them thinking he were joking with his friends. He learned how to control his strength after practice" (S1).

"...he reacted with various behaviors in order not to obey our instructions. And these reactions often appeared as unwanted behavior. I think he understood that with the sense of accomplishment in the games, the instructions were not too bad" (S1).

\section{Discussion}

The aim of this study was to examine the effect of peer-mediated adaptive physical activity program on problem behaviors of mentally handicapped students. In addition, one-to-one interviews were conducted with teachers of mentally handicapped students to support the quantitative findings.

In the quantitative aspect of the study, it was determined that the peer-mediated APA program created a significant difference between pre-test, post-test and follow-up tests related to problem behavior levels of mentally handicapped students. The Wilcoxon Signs test was used as a non-parametric post hoc analysis in order to determine which measurements were among these differences. Test results showed a significant difference between pre-test - post-test and follow-up test - pre-test scores. However, there was no significant difference between post-test - follow-up test scores. This showed that peer-mediated APA program contributed positively to problem behavior levels of mentally handicapped students. In addition, the lack of significant differences in the analysis conducted between the final test and the follow-up test revealed that these skills acquired by mentally handicapped students were maintained three weeks after the completion of the practices.

There are studies investigating the effects of exercise, physical activity and play on problem behaviors of mentally handicapped individuals in the literature (Bachman \& Sluyter, 1988; Baumeister \& MacLean, 1984; Gencoz, 1997; Güngör, Yılmaz, \& İlhan, 2019; Cannella-Malone et al., 2011; Elliott et al., 1994; Jones et al., 2008; Kern et al., 1982; Lancioni et al., 1984; McGimsey \& Favell, 1988).

In the study by Bachman and Sluyter (1988), it was reported that 30-day exercise program had positive effects on general behavior problems of mentally handicapped individuals. In their study, Baumeister and MacLean (1984) stated that the 6-week exercise program made a positive contribution to the self-harm behavior of individuals aged 19-23 years who were severely mentally handicapped. In the study of Gencoz (1997), it was stated that 7-week basketball program has contributed positively to the general behavior of mentally handicapped individuals aged from 10-14. In the literature, national and international studies have shown that exercise, physical activity and game-based interventions have positive effects on behavioral problems of mentally handicapped individuals. The quantitative results of the research in the literature and the current research are consistent.

In addition to the effectiveness findings, monitoring data were also obtained. When the qualitative findings of the study were examined, it was seen that the quantitative findings were supported and accordingly, the opinions became more prominent. It can be said that the effectiveness findings that were obtained by pre-test and post-test measurements were reinforced by positive changes in the behavioral problems defined by the teachers as "Increase in behavior appropriate to the classroom atmosphere", "Getting on with peers without push-pull behavior", "Elimination of touch-related discomfort", "Confidence acquisition", "Decreased fears based on peer 
and teacher relationships", "Acquisition of power control", "Acquisition of behavioral models according to the instructions".

\section{References}

Acar, Ç. (2000). Zihin özürlü çocuklarla çalışan özel eğitim öğretmenlerinin sinıflarında karşılaştıkları problem davranışlarla ilgili görüş ve önerileri. Yüksek Lisans Tezi, Anadolu Üniversitesi Eğitim Bilimleri Enstitüsü, Eskişehir.

Acar, Ç., \& Batu, S. (2001). Özel eğitim öğretmenlerinin sınıflarında karşılaştıkları problem davranışlarla ilgili görüs ve önerileri (pp. 86-95). 10. Ulusal Özel Eğitim Kongresi Bildirileri (Mart 2001): Antakya, Hatay.

Antshel, K. M., Phillips, M. H., Gordon, M., Barkley, R., \& Faraone, S. V. (2006). Is ADHD a valid disorder in children with intellectual delays? Clinical Psychology Review, 26(5), 555-572. https://doi.org/10.1016/j.cpr.2006.03.002

Bachman, J. E., \& Sluyter, D. (1988). Reducing inappropriate behaviors of developmentally disabled adults using antecedent aerobic dance exercises. Research in Developmental Disabilities, 9(1), 73-83. https://doi.org/10.1016/0891-4222(88)90021-2

Baumeister, A. A., \& MacLean Jr, W. E. (1984). Deceleration of self-injurious and stereotypie responding by exercise. Applied Research in Mental Retardation, 5(3), 385-393. https://doi.org/10.1016/S0270-3092(84)80059-4

Bhatia, K., Kabra, M., \& Sarpa, S. (2005). Ehavioral problems in children with Down Syndrome. Indian Pediatrics, 42(17), 675-680.

Brown, W. H., Odom, S. L., \& McConnell, S. R. (Eds.). (2008). Social competence of young children: Risk, disability, and intervention. Baltimore, MD: Brookes.

Cannella-Malone, H. I., Fleming, C., Chung, Y. C., Wheeler, G. M., Basbagill, A. R., \& Singh, A. H. (2011). Teaching daily living skills to seven individuals with severe intellectual disabilities: A comparison of video prompting to video modeling. Journal of Positive Behavior Interventions, 13(3), 144-153. https://doi.org/10.1177/1098300710366593

Carter, E. W., \& Hughes, C. (2005). Increasing social interaction among adolescents with intellectual disabilities and their general education peers: Effective interventions. Research and Practice for Persons with Severe Disabilities, 30(4), 179-193. https://doi.org/10.2511/rpsd.30.4.179

Çiftçi, İ., \& İnce, N. (2002). Zihinsel engelli öğrencilerin davranıs problemlerinin öğretmen adayları tarafindan incelenmesi (pp. 149-162). XXII. Ulusal Özel Eğitim Kongresi (112 Kasım 2002).

Çiftçi, İ., \& Tabak, Ö. (1997). Zihinsel engellilerde görülen problem davranışların belirlenmesi (pp. 7-48). Özel Eğitim Günleri Bildiri kitabı. Kasım.

Cooper, S. A., Smiley, E., Jackson, A., Finlayson, J., Allan, L., Mantry, D., \& Morrison, J. (2009). Adults with intellectual disabilities: prevalence, incidence and remission of aggressive behaviour and related factors. $\begin{array}{lllll}\text { Journal of Intellectual Disability } & \text { Research, 53(3), 217-232. }\end{array}$ https://doi.org/10.1111/j.1365-2788.2008.01127.x

Creswell, J. W., \& Clark, V. L. P. (2017). Designing and conducting mixed methods research. California: Sage publications.

Crnic, K., Hoffman, C., Gaze, C., \& Edelbrock, C. (2004). Understanding the emergence of behavior problems in young children with developmental delays. Infants \& Young Children, 17(3), 223-235. https://doi.org/10.1097/00001163-200407000-00004

Dekker, M. C., Nunn, R. J., \& Koot, H. M. (2002). Psychometric properties of the revised Developmental Behavior Checklist scales in Dutch children with intellectual disability. Journal of Intellectual Disability, 46(19), 61-75. https://doi.org/10.1046/j.1365-2788.2002.00353.x

DiSalvo, C. A., \& Oswald, D. P. (2002). Peer-mediated interventions to increase the social interaction of children with autism: Consideration of peer expectations. Focus on Autism and Other Developmental Disabilities, 17, 198-207. https://doi.org/10.1177/10883576020170040201

Dodson, L. C., \& Mullens, W. R. (1969). Some effects of jogging on psychiatric hospital patients. American Corrective Therapy Journal, 23(5), 130-134. Retrived from https://europepmc.org/article/med/5344911

Duker, P. C., Van Druenen, C., Jol, K., \& Oud, H. (1986). Determinants of maladaptive behavior of 
institutionalized mentally retarded individuals. American Journal of Mental Deficiency, 91(1), 51-56. Retrived from https://psycnet.apa.org/record/1986-28145-001

Dykens, E. M. (2000). Annotation: Psychopathology in children with intellectual disability. The Journal of Child Psychology and Psychiatry and Allied Disciplines, 41(4), 407-417. https://doi.org/10.1111/1469-7610.00626

Ekiz, D. (2009). Bilimsel araştırma yöntemleri: Yaklaşım, yöntem ve teknikler. Ankara: Anı Yayıncılık.

Elliott, R. O., Dobbin, A. R., Rose, G. D., \& Soper, H. V. (1994). Vigorous, aerobic exercise versus general motor training activities: Effects on maladaptive and stereotypic behaviors of adults with both autism and mental retardation. Journal of Autism and Developmental Disorders, 24(5), 565-576. https://doi.org/10.1007/BF02172138

Emerson, E. (2005). Underweight, obesity and exercise among adults with intellectual disabilities in supported accommodation in Northern England. Journal of Intellectual Disability Research, 49(2), 134-143. https://doi.org/10.1111/j.1365-2788.2004.00617.x

Emerson, E., \& Einfeld, S. L. (2011). Challenging behaviour. Cambridge University Press. https://doi.org/10.1017/CBO9780511861178

Emmons, P., \& Anderson, L. (2005). Understanding sensory dysfunction: learning, development and sensory dysfunction in autism spectrum disorders, ADHD, learning disabilities and bipolar disorder. Londra: Jessica Kingsley Publishers.

Fragala-Pinkham, M. A., Haley, S. M., Rabin, J., \& Kharasch, V. S. (2005). A fitness program for children with disabilities. Physical Therapy, 85(11), 1182-1200. https://doi.org/10.1093/ptj/85.11.1182

Freund, L. S., \& Reiss, A. L. (1991). Cognitive profiles associated with the fra (X) syndrome in males and females. American Journal of Medical Genetics, 38(4), 542-547. https://doi.org/10.1002/ajmg.1320380409

Gabler-Halle, D., Halle, J. W., \& Chung, Y. B. (1993). The effects of aerobic exercise on psychological and behavioral variables of individuals with developmental disabilities: A critical review. Research in Developmental Disabilities, 14(5), 359-386. https://doi.org/10.1016/0891-4222(93)90009-9

García-Villamisar, D. A., \& Dattilo, J. (2010). Effects of a leisure programme on quality of life and stress of individuals with ASD. Journal of Intellectual Disability Research, 54(7), 611-619. https://doi.org/10.1111/j.1365-2788.2010.01289.x

Gençöz, F. (1997). The effects of basketball training on the maladaptive behaviors of trainable mentally retarded children. Research in Developmental Disabilities, 18(1), 1-10. https://doi.org/10.1016/S0891-4222(96)00029-7

Gresham, F. M., \& Elliott, S. N. (1990). Social skills rating system: Manual. American Guidance Service.

Güngör, N. B., Ylmaz, A., \& İlhan, E. L. (2019). Gains of a special athlete in the context of quality of life: a case study in line with parent opinions. Ankara University Faculty of Educational Sciences Journal of Special Education, 20(3), 421-443. https://doi.org/10.21565/ozelegitimdergisi.488740

Gutman, S. A., Raphael, E. I., Ceder, L. M., Khan, A., Timp, K. M., \& Salvant, S. (2010). The effect of a motor-based, social skills intervention for adolescents with high-functioning autism: Two single-subject design cases. Occupational Therapy International, 17(4), 188-197. https://doi.org/10.1002/oti.300

Gutman, S. A., Raphael-Greenfield, E. I., \& Rao, A. K. (2012). Effect of a motor-based role-play intervention on the social behaviors of adolescents with high-functioning autism: Multiple-baseline single-subject design. American Journal of Occupational Therapy, 66(5), 529-537. https://doi.org/10.5014/ajot.2012.003756

Holden, B., \& Gitlesen, J. P. (2006). A total population study of challenging behaviour in the county of Hedmark, Norway: Prevalence, and risk markers. Research in Developmental Disabilities, 27(4), 456-465.https://doi.org/10.1016/j.ridd.2005.06.001

İlhan, E. L. (2007). Eğitilebilir zihinsel engelli çocuklarda beden eğitimi ve sporun sosyalleşme düzeylerine etkisi. Kastamonu Eğitim Dergisi, 16(1), 315-324.

İlhan, L. (2008). Zihinsel engelli çocuklar için beden eğitimi ve sporun genel gelişim süreçleri açısından önemi. Cagdas Egitim Dergisi, 350, 17-24.

Jones, M. C., Cooper, C., Smiley, E., Allan, L., Williamson, A., \& Morrison, J. (2008). Prevalence of, and factors associated with, problem behaviors in adults with intellectual disabilities. Journal of Nervous and 
Mental Disease, 196, 678-686. https://doi.org/10.1097/NMD.0b013e318183f85c

Kaner, S. (2009). Aile katılımı ve işbirliği (B. Sucuoğlu Ed.). Zihin engelliler.

Kerker, B. D., Owens, P. L., Zigler, E., \& Horwitz, S. M. (2004). Mental health disorders among individuals with mental retardation: Challenges to accurate prevalence estimates. Public Health Reports, 119(4), 409-417. https://doi.org/10.1016/j.phr.2004.05.005

Kern, L., Koegel, R. L., Dyer, K., Blew, P. A., \& Fenton, L. R. (1982). The effects of physical exercise on self-stimulation and appropriate responding in autistic children. Journal of Autism and Developmental Disorders, 12(4), 399-419. https://doi.org/10.1007/BF01538327

Kiernan, C., \& Kiernan, D. (1994). Challenging behaviour in schools for pupils with severe learning difficulties. Mental Handicap Research, 7(3), 177-201. https://doi.org/10.1111/j.1468-3148.1994.tb00126.x

Kunzi, K. (2015). Improving social skills of adults with autism spectrum disorder through physical activity, sports, and games: A review of the literature. Adultspan Journal, 14(2), 100-113. https://doi.org/10.1002/adsp.12008

Lancioni, G. E., Smeets, P. M., Ceccarani, P. S., Capodaglio, L., \& Campanari, G. (1984). Effects of gross motor activities on the severe self-injurious tantrums of multihandicapped individuals. Applied Research in Mental Retardation, 5(4), 471-482. https://doi.org/10.1016/S0270-3092(84)80039-9

Leaf, J. B., Taubman, M., Bloomfield, S., Palos-Rafuse, L., Leaf, R., McEachin, J., \& Oppenhaim., M. L. (2009). Increasing social skills and pro-social behavior for three children diagnosed with autism through the use of a teaching package. Research in Autism Spectrum Disorders, 3(1), 278-289. https://doi.org/10.1016/j.rasd.2008.07.003

Lundqvist, L. O. (2013). Prevalence and risk markers of behavior problems among adults with intellectual disabilities: A total population study in Örebro County, Sweden. Research in Developmental Disabilities, 34(4), 1346-1356. https://doi.org/10.1016/j.ridd.2013.01.010

Matson, J. L., Minshawi, N. F., Gonzalez, M. L., \& Mayville, S. B. (2006). The relationship of comorbid problem behaviors to social skills in persons with profound mental retardation. Behavior Modification, 30(4), 496-506. https://doi.org/10.1177/0145445505283415

McGimsey, J. F., \& Favell, J. E. (1988). The effects of increased physical exercise on disruptive behavior in retarded persons. Journal of Autism and Developmental Disorders, 18(2), 167-179. https://doi.org/10.1007/BF02211944

Menear, K. S., \& Neumeier, W. H. (2015). Promoting physical activity for students with autism spectrum disorder: Barriers, benefits, and strategies for success. Journal of Physical Education, Recreation and Dance, 86(3), 43-48. https://doi.org/10.1080/07303084.2014.998395

Messent, P. R., Cooke, C. B., \& Long, J. (1998). Physical activity, exercise and health of adults with mild and moderate learning disabilities. British Journal of Learning Disabilities, 26(1), 17-22. https://doi.org/10.1111/j.1468-3156.1998.tb00041.x

Nunley, R. L. (1965). A physical fitness program for the mentally retarded in the public schools. Physical Therapy, 45(10), 947. https://doi.org/10.1093/ptj/45.10.946

Özaydin, L., Tekin-Iftar, E., \& Kaner, S. (2008). Arkadaslik becerilerini gelistirme programinin özel gereksinimi olan okul öncesi çocuklarinin sosyal etkilesimlerine etkisi. Ozel Egitim Dergisi, 9(1), 15. Retrived from https://search.proquest.com/openview/066bd61dde310767d67d6eb1861ccd65/1?pq-origsite=gscholar\&cb= 75759

Özen, A., Çolak, A., \& Acar, Ç. (2002). Zihin özürlü çocuğa sahip annelerin günlük yaşamda karşılaştıkları problem davranışlarla ilgili görüssleri. Özel Eğitim Dergisi, 3(2), 1-13. https://doi.org/10.1501/Ozlegt_0000000066

Ozer, D., Baran, F., Aktop, A., Nalbant, S., Aglamis, E., \& Hutzler, Y. (2012). Effects of a Special Olympics Unified Sports soccer program on psycho-social attributes of youth with and without intellectual disability. Research in Developmental Disabilities, 33(1), 229-239. https://doi.org/10.1016/j.ridd.2011.09.011

Polloway, E. A., Epstein, M. H., \& Cullinan, D. (1985). Prevalence of behavior problems among educable mentally retarded students. Education and Training of the Mentally Retarded, 3-13. Retrieved from http://www.jstor.org/stable/23877278 
Poppes, P., Van der Putten, A. J. J., \& Vlaskamp, C. (2010). Frequency and severity of challenging behaviour in people with profound intellectual and multiple disabilities. Research in Developmental Disabilities, 31(6), 1269-1275. https://doi.org/10.1016/j.ridd.2010.07.017

Rush, K. S., Bowman, L. G., Eidman, S. L., Toole, L. M., \& Mortenson, B. P. (2004). Assessing psychopathology in individuals with developmental disabilities. Behavior Modification, 28(5), 621-637. https://doi.org/10.1177/0145445503259830

Russell, A. T., \& Forness, S. R. (1985). Behavioral disturbance in mentally retarded children in TMR and EMR classrooms. American Journal of Mental Deficiency, 89(4), 338-344. Retrived from https://psycnet.apa.org/record/1985-15886-001

Sazak-Pınar, E., \& Tekinarslan-Çiftçi, İ. (2003). Zihin engelli birey için hazırlanan akran aracılı sosyal beceri öğretim programının etkililiğinin incelenmesi. Ankara Üniversitesi Eğitim Bilimleri Fakültesi Özel Ĕgitim Dergisi, 4(2), 13-30. https://doi.org/10.1501/Ozlegt_0000000204

Semmel, M. I., \& Gao, X. (1992). Teacher perceptions of the classroom behaviors of nominated handicapped and nonhandicapped students in China. The Journal of Special Education, 25(4), 415-430. https://doi.org/10.1177/002246699202500402

Sjgafoos, J., Elkins, J., Kerr, M., \& Attwood, T. (1994). A survey of aggressive behaviour among a population of persons with intellectual disability in Queensland. Journal of Intellectual Disability Research, 38(4), 369-381. https://doi.org/10.1111/j.1365-2788.1994.tb00417.x

Srinivasan, S. M., Pescatello, L. S., \& Bhat, A. N. (2014). Current perspectives on physical activity and exercise recommendations for children and adolescents with autism spectrum disorders. Physical Therapy, 94(6), 1-46. https://doi.org/10.2522/ptj.20130157

Stanish, H. I., \& Temple, V. A. (2012). Efficacy of a peer - guided exercise programme for adolescents with intellectual disability. Journal of Applied Research in Intellectual Disabilities, 25(4), 319-328. https://doi.org/10.1111/j.1468-3148.2011.00668.x

Staples, K. L., Reid, G., Pushkarenko, K., \& Crawford, S. (2011). Physically active living for individuals with ASD. In J. L. Matson \& P. Sturmey (Eds.), International handbook of autism and pervasive developmental disorders (pp. 397-412). New York: Springer Science and Business Media. https://doi.org/10.1007/978-1-4419-8065-6_25

Sucuoğlu, B. (2003). Sorun Davranışlar Kontrol Listesi Türkçe Formu'nun psikometrik özelliklerinin incelenmesi. Türk Psikoloji Dergisi, 18(52), 77-91. Retrived from $\mathrm{http}: / /$ psikiyatridizini.net/viewarticle. aspx?articleid=21399\&tammetinvar=yes

Sucuoğlu, B., \& Özokçu, O. (2005). Kaynaştırma öğrencilerinin sosyal becerilerinin değerlendirilmesi. Ankara Üniversitesi Eğitim Bilimleri Fakültesi Özel Eğitim Dergisi, 6(01), 41-65. https://doi.org/10.1501/Ozlegt_0000000086

Temple, V. A., \& Stanish, H. I. (2011). The feasibility of using a peer-guided model to enhance participation in community-based physical activity for youth with intellectual disability. Journal of Intellectual Disabilities, 15(3), 209-217. https://doi.org/10.1177/1744629511422137

Todd, T., \& Reid, G. (2006). Increasing physical activity in individuals with autism. Focus on Autism and Other Developmental Disabilities, 21(3), 167-176. https://doi.org/10.1177/10883576060210030501

Vatter, G. (1998). Diagnosis of Autism in Children with Down syndrome. Retrived from http://www.riverbendds.org/index. htm

Yarımkaya, E. (2018). Akran aracılı uyarlanmış fiziksel aktivitelerin orta düzeyde zihin yetersizliği olan öğrencilerin sosyalleşme düzeyleri üzerine etkisi. Kastamonu Education Journal, 26(2), 335-344. https://doi.org/10.24106/kefdergi.389805

Yarımkaya, E., İlhan, E. L., \& Karasu, N. (2017). Akran aracılı uyarlanmış fiziksel aktivitelere katılan otizm spektrum bozukluğu olan bir bireyin iletişim becerilerindeki değişimlerin incelenmesi. Ankara Üniversitesi Ĕgitim Bilimleri Fakültesi Özel Eğitim Dergisi, 18(02), 225-252. https://doi.org/10.21565/ozelegitimdergisi.319423

Zarkowska, E., \& Clements, J. (1994). Severe Problem Behaviour: The STAR Approach. London: Chapman Hall.

Zascavage, V., \& Winterman, K. G. (2009). What middle school educators should know about assistive 
technology and universal design for learning. Middle School Journal, 40(4), 46-52. https://doi.org/10.1080/00940771.2009.11461681

\section{Copyrights}

Copyright for this article is retained by the author, with first publication rights granted to the journal.

This is an open-access article distributed under the terms and conditions of the Creative Commons Attribution license (http://creativecommons.org/licenses/by/4.0/). 